\title{
Impact of soil erodibility factor estimation on the distribution of sediment loads: the LaTrobe River catchment case study
}

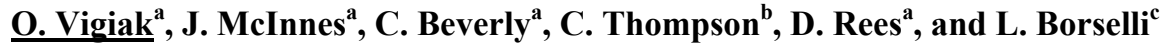 \\ ${ }^{a}$ Department of Primary Industries, Future Farming Systems Research division, Rutherglen centre, \\ Rutherglen, Victoria. \\ Email: olga.vigiak@dpi.vic.gov.au \\ ${ }^{b}$ Integrated Catchment Assessment and Management (iCAM) Centre, The Fenner School of Environment and \\ Society, The Australian National University, Australian Capital Territory Integrated Catchment Assessment \\ ${ }^{c}$ Instituto de Geologia. Fac. De Ingegneria. Universitad Autonoma de San Lui Potosì, Av. Dr Manuela Nava \\ 5, C.P., 78240 San Luis Potosi, S.L.P., Mexico
}

\begin{abstract}
The soil erodibility factor $(\mathrm{K})$ is used in empirical erosion models based on the Universal Soil Loss Equation to account for soil susceptibility to detachment and transport by rainfall and runoff. Whilst soil erodibility is ideally measured from long-term standard plots, in catchment-scale modelling it is more often estimated by applying pedo-transfer functions. These are either based on soil properties reported in soil databases, or attributed by experts on the basis of soil characteristics. The aim of this study was to evaluate the impact of the soil erodibility factor on the amount and distribution of suspended sediment loads generated by hillslope erosion within the LaTrobe River catchment, in Victoria (south-east Australia).
\end{abstract}

Two soil erodibility factor sets were developed for hydrologic soil groups in the LaTrobe catchment. The first ('local') set was based on a Victorian soil database; soil erodibility was attributed by an expert soil scientist on the basis of topsoil texture, soil structure, geology, hydrological properties of the profile, and local knowledge. The second ('global') set was derived from a global soil erodibility dataset using the probabilistic distribution of $\mathrm{K}$ based on climatic conditions, skeleton (i.e. fraction $>2 \mathrm{~mm}$ ), organic matter content, and topsoil texture. The $\mathrm{K}$ factor in the 'local' set ranged from 0.015 to $0.055 \mathrm{Mg} \mathrm{ha} \mathrm{h} \mathrm{ha}{ }^{-1} \mathrm{MJ}^{-1} \mathrm{~mm}^{-}$ 1 , whereas soil erodibility in the 'global' set had higher absolute values but a smaller range $(0.044-0.067 \mathrm{Mg}$ ha $\mathrm{h} \mathrm{ha}^{-1} \mathrm{MJ}^{-1} \mathrm{~mm}^{-1}$ ). Importantly, the two sets differed in ranking soils from the most to the least erodible. A catchment scale model based on CatchMODS was used to assess suspended sediment loads from three erosion processes: hillslope erosion (which depended on soil erodibility), gully, and streambank erosion. The model estimated deposition of suspended sediment on hillslopes, floodplains and in reservoirs. Hillslope deposition was calculated using a hillslope sediment delivery ratio (HSDR), which is a calibration parameter. The two model configurations (i.e. informed by the two erodibility factor sets) were calibrated independently using annual suspended sediment load estimates at ten water quality monitoring stations of the catchment for the period 1990-2005. The model performance was assessed in terms of model efficiency of specific sediment yield predictions.

The calibration of HSDR did reduce the impact of absolute values of soil erodibility estimates on hillslope net erosion; with higher HSDR calibrated for the local $\mathrm{K}$ configuration. However, the two model configurations resulted in different contribution of hillslope net erosion to suspended sediment loads: in the local $\mathrm{K}$ dataset configuration, hillslope net erosion contribution was estimated at $3.6 \mathrm{kt} / \mathrm{y}$ in the local $\mathrm{K}$ configuration (11\% of a total of $34 \mathrm{kt} / \mathrm{y}$ estimated to reach Lake Wellington). In the global dataset configuration, hillslope net erosion was estimated at $9 \mathrm{kt} / \mathrm{y}(23 \%$ of an estimated total of $40 \mathrm{kt} / \mathrm{y}$ at the lake).

The spatial distribution of the soil erodibility factor $(\mathrm{K})$ resulted in a measurable impact on model performance; the global $\mathrm{K}$ configuration better matched specific sediment load observations across the catchment (efficiency of 0.32 ). The main difference in the attribution of $\mathrm{K}$ by the two approaches was due to the influence of climatic conditions. Analysis of the global dataset indicated that, other conditions being equal, soil erodibility in warm climates is lower than in temperate climates (Salvador Sanchis et al., 2008). Apparently, the local dataset underestimated the climatic effect on soil erodibility, and resulted in an overall underestimation of net hillslope erosion in the study catchment. These exploratory results will need to be further explored in future research.

Keywords: Soil erodibility, CatchMODS, LaTrobe River, Gippsland Lakes 
Vigiak et al., Impact of soil erodibility factor estimation on the distribution of sediment loads: the Latrobe River catchment case study

\section{INTRODUCTION}

The soil erodibility factor $(\mathrm{K})$ is used in empirical erosion models based on the Universal Soil Loss Equation (USLE; Wishmeier and Smith, 1978) to account for soil susceptibility to detachment and transport by rainfall and runoff. Whilst soil erodibility is ideally measured from long-term standard plots, in catchment-scale modelling it is more often estimated by applying pedo-transfer functions (e.g. Lu et al., 2003; Salvador Sanchis et al., 2008; Borselli et al., 2009). These are either based on soil properties reported in soil databases, or attributed by experts on the basis of soil characteristics.

Catchment-scale erosion models that estimate gross erosion on the hillslope with the USLE-type approach, i.e. empirical or conceptual models, typically introduce the concept of a hillslope 'sediment delivery ratio' (HSDR) to account for deposition along the hillslopes (e.g. Lu et al., 2006; Vigiak et al., in press). The hillslope sediment delivery ratio (HSDR) is defined as the fraction of gross erosion that is transported from a given catchment in a given time interval to the stream network. In effect, HSDR is a scaling factor that relates sediment availability and deposition at different spatial scales ( $\mathrm{Lu}$ et al., 2006). Measurements of gross erosion are generally unavailable; more often, at the catchment scale models are calibrated and validated against sediment loads monitored at gauging stations across the study area. This approach allows an estimation of the net hillslope erosion which is, however, the net result of the combined effect of gross erosion (which depends among other factors upon soil erodibility), and the choice of HSDR parameter. Clearly, calibration of HSDR might counteract an over- or under-prediction of soil erodibility and therefore of gross hillslope erosion. However, soil erodibility, being dependent upon soil characteristics, varies in space. It is therefore not obvious how the counteracting effects of soil erodibility attribution and HSDR calibration may affect the final performance of a conceptual catchment-scale model.

The aim of this study was to evaluate the impact of the soil erodibility factor on the amount and distribution of suspended sediment loads generated by hillslope erosion within the LaTrobe River catchment, in Victoria (south-east Australia). Two working hypotheses were formulated; 1) the calibration of a HSDR reduces the impact of absolute values of soil erodibility estimates on hillslope net erosion, and therefore the model configurations based on different soil erodibility estimations will result in similar contribution of hillslope net erosion to suspended sediment loads; 2) the spatial distribution of soil erodibility impacts on model performance defined by matching specific sediment load observations across the catchment.

\section{THE LATROBE RIVER CATCHMENT}

The LaTrobe River is the largest and western most river of the Gippsland Lakes Basin (Figure 1). The LaTrobe River carries approximately half of the discharge and the highest sediment and nutrient loads to Lake Wellington (Grayson et al., 2001; EPA, 2002). It has a catchment area of approximately $4900 \quad \mathrm{~km}^{2}$ (approximately $23 \%$ of the Gippsland Lakes Basin). The Mean Annual Flow into the Lake is approximately 980,000 ML (EPA, 2002). Over one third of the catchment is cleared, mostly for cattle and sheep grazing. The catchment's climate is classified as temperate, with warm summer but no dry season ( $\mathrm{Cfb}$ according to Köppen-Geiger classification; Peel et al., 2007). Three landscape zones can be distinguished (EPA, 2002). The Alpine Highlands in the north, mostly forested, cover $10 \%$ of the catchment

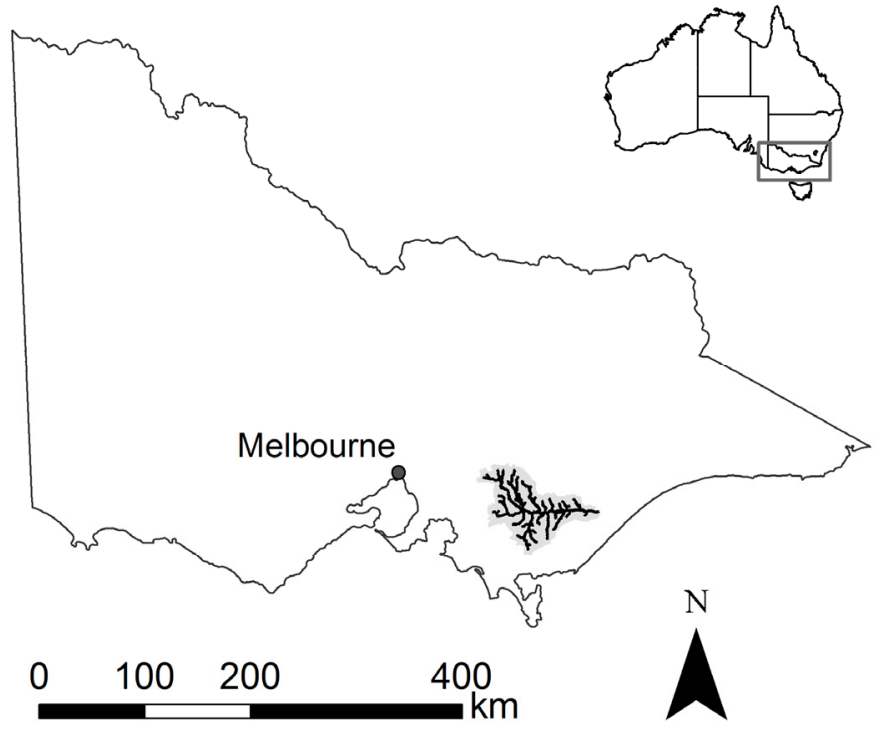

Figure 1. The Latrobe River catchment. and receive high precipitation $(\sim 1600 \mathrm{~mm} / \mathrm{y})$ sometimes in form of snow. The cleared hills at the footslopes are mostly used for dryland pastures and horticulture. The coastal plains receive about $600 \mathrm{~mm} / \mathrm{y}$ and are intensively cultivated for irrigated agriculture and pasture. Urban and industrial activities (coal mines) cover about $5 \%$ of the catchment. Three major impoundments regulate the flow along the LaTrobe River: the Blue 
Vigiak et al., Impact of soil erodibility factor estimation on the distribution of sediment loads: the Latrobe River catchment case study

Rock Lake on the Tanjil River, Moondarra Reservoir on the Tyers River, and Lake Narracan on the LaTrobe River (EPA 2002; Hancock et al., 2007).

\section{SOIL PROPERTIES AND ERODIBILITY ASSESSMENT}

Soil information for the catchment (Aldrick et al., 1992; Sargeant and Imhof, 2011) was interpreted to classify soils into hydrologic groups (Figure 2). The soil group map results from the juxtaposition of different soil survey sources, which may cause artificial boundaries, such as the horizontal line separating the Friable Earths from texture contrast soils. The map accuracy is higher in agricultural land than in public land. Ten hydrologic soil groups were defined on the basis of soil profile characteristics; permeability, water retention capacity, topsoil texture and organic matter content (Table 1).

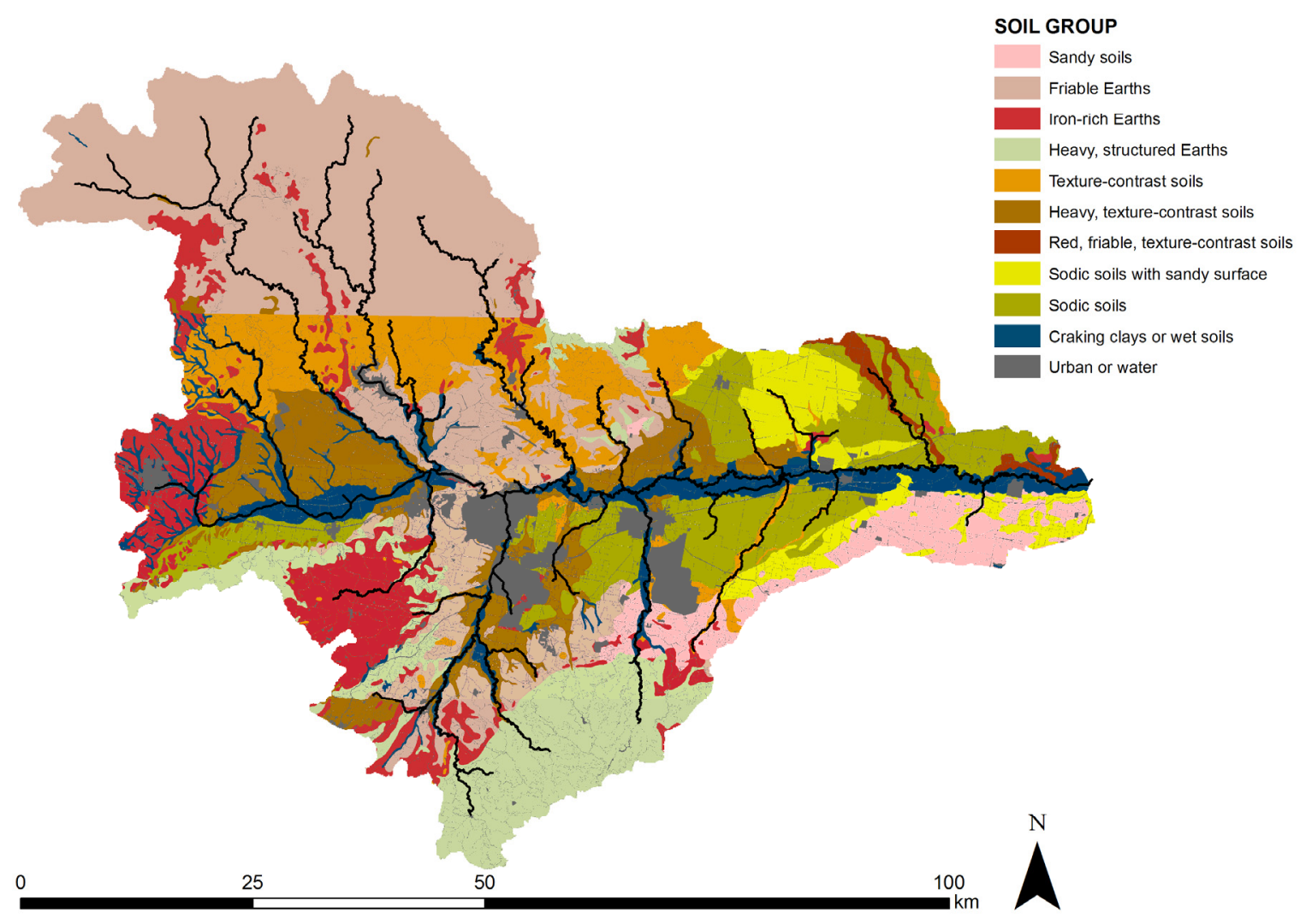

Figure 2. Soil group map of the Latrobe River catchment.

The soil erodibility factor $\mathrm{K}$ for each of the ten groups was estimated using two pedo-transfer approaches. The first set of K values ('local') was based on a Victorian soil database (Rab et al., 2002). Soil erodibility was attributed by an expert soil scientist on the basis of topsoil texture, soil structure, geology, and hydrological properties of the profile. The soil erodibility factor $\mathrm{K}$ in the 'local' set ranged from 0.015 to $0.055 \mathrm{Mg}$ ha h ha ${ }^{-1} \mathrm{MJ}^{-1} \mathrm{~mm}^{-1}$ (Table 1).

The second set of K values ('global') was derived from a global K dataset using the probabilistic distribution of soil erodibility based on climatic conditions (Köppen-Geiger climatic group classification), skeleton (i.e. fraction $>2 \mathrm{~mm}$ ), organic matter content, and topsoil texture (Salvador Sanchis et al., 2008) and using the procedure described in Borselli et al. (2009), assigning to each soil group the median K value of the global distribution. The 'global' $\mathrm{K}$ values in the LaTrobe catchment were generally higher than the 'local' $\mathrm{K}$ values, but varied over a smaller range $\left(0.044-0.067 \mathrm{Mg} \mathrm{ha} \mathrm{ha} \mathrm{ha}^{-1} \mathrm{MJ}^{-1} \mathrm{~mm}^{-1}\right)$. Importantly, the two sets differed in ranking soils from the most to the least erodible.

\section{CATCHMENT SCALE MODELLING FRAMEWORK}

Suspended sediment loads for the period 1990-2005 were assessed using a point-to-catchment modelling framework described in Vigiak et al. (2011a), and based on CatchMODS (Newham et al., 2004). Three 
Vigiak et al., Impact of soil erodibility factor estimation on the distribution of sediment loads: the Latrobe River catchment case study

Table 1. Soil groups of the LaTrobe catchment, with representative topsoil texture and organic carbon content. USLE soil erodibility $\mathrm{K}$ factor $\left(\mathrm{Mg}\right.$ ha h ha $\left.{ }^{-1} \mathrm{MJ}^{-1} \mathrm{~mm}^{-1}\right)$ as estimated from a local database (Rab et al., 2002) and a global dataset (Salvador Sanchis et al., 2008; Borselli et al., 2009).

\begin{tabular}{|c|c|c|c|c|c|c|c|}
\hline Soil group & $\begin{array}{c}\text { Australian Soil } \\
\text { Classification (ASC)* }\end{array}$ & $\begin{array}{c}\text { Dominant } \\
\text { Principal } \\
\text { Profile Form\# }\end{array}$ & $\begin{array}{l}\text { Clay } \\
(\%)\end{array}$ & $\begin{array}{l}\text { Sand } \\
(\%)\end{array}$ & $\begin{array}{l}\text { O.C. } \\
(\%)\end{array}$ & Local $\mathrm{K}_{\dagger}$ & Global $\mathrm{K}^{\wedge}$ \\
\hline Sandy soils & Podosols; Tenosols & $\mathrm{Uc} 2.3$ & 1 & 35 & 12 & 0.015 & 0.056 \\
\hline $\begin{array}{l}\text { Friable Earths } \\
\text { (uplands) }\end{array}$ & Kandosols; Dermosols & Um5, Gn4.11 & 19 & 43 & 11 & 0.040 & 0.052 \\
\hline $\begin{array}{l}\text { Friable, red, iron rich } \\
\text { structured Earths. }\end{array}$ & Ferrosols & Gn3.11 & 48 & 24 & 2.4 & 0.025 & 0.045 \\
\hline Heavy structured Earths & Dermosols & Gn4.81, Gn3.91 & 38 & 13 & 4.3 & 0.030 & 0.067 \\
\hline Texture-contrast soils & $\begin{array}{l}\text { Kurosols; Chromosols; } \\
\text { Dermosols }\end{array}$ & Dy3.41 & 18 & 38 & 0.5 & 0.055 & 0.055 \\
\hline $\begin{array}{l}\text { Heavy (clayey) Earths } \\
\text { and texture contrast } \\
\text { soils }\end{array}$ & Dermosols; Chromosols & Dy3.41, Gn2. & 15 & 56 & 3.9 & 0.040 & 0.044 \\
\hline $\begin{array}{l}\text { Red, friable, texture- } \\
\text { contrast soils }\end{array}$ & Chromosols; Dermosols & Dr2.32. Gn3.18 & 13 & 57 & 1.1 & 0.040 & 0.053 \\
\hline $\begin{array}{l}\text { Sodic, texture- contrast } \\
\text { soils with sandy surface }\end{array}$ & $\begin{array}{l}\text { Yellow, Brown and } \\
\text { Grey Sodosols }\end{array}$ & Dy3.42 & 13 & 48 & 4.7 & 0.035 & 0.054 \\
\hline $\begin{array}{l}\text { Sodic, texture- contrast } \\
\text { soils }\end{array}$ & $\begin{array}{l}\text { Yellow, Brown and } \\
\text { Grey Sodosols }\end{array}$ & Dy3.43 & 22 & 35 & 4.0 & 0.025 & 0.050 \\
\hline $\begin{array}{l}\text { Cracking Clays and wet } \\
\text { soils }\end{array}$ & Vertosols; Hydrosols & $\mathrm{Ug}, \mathrm{Dg}, \mathrm{Dd}$ & 41 & 34 & 2.8 & 0.018 & 0.049 \\
\hline
\end{tabular}

*(Isbell, 2002); \#(Northcote, 1979); †(Rab et al., 2002); ^(Salvador Sanchis et al., 2008)

erosion processes were accounted for: hillslope, gully, and streambank erosion. Hillslope gross erosion for any soil and land use combination (hydrologic response units) was estimated using the point-scale model Howleaky2010 (McClymont et al., 2008), which estimated soil loss as a function of land cover, runoff volume and soil erodibility. Point-scale gross erosion was upscaled to subcatchments of approximately 40 $\mathrm{km}^{2}$ in size on the basis of the subcatchment composition (i.e. proportion of soils and land uses) and topography (represented by the mean USLE topography factor LS of the subcatchment; Vigiak et al., 2011a).

Average annual suspended load (t/y) due to gully erosion assumed sediments to be sourced from sidewall retreat of permanent gullies, and was estimated per subcatchment as a function of gully length (m), estimated rate of gully wall retreat, expressed as average annual cross-section enlargement $\left(\mathrm{m}^{2} / \mathrm{y}\right)$, soil density of gully wall $\left(\mathrm{t} / \mathrm{m}^{3}\right)$, and fraction $\Delta$ of particles $<63 \mu \mathrm{m}$ in the gully wall (proportion). Estimation of gully extent and rate of gully erosion in the region are reported in McInnes et al. (unpublished data).

Streambank suspended sediment load was estimated as a function of the river stream power (de Rose et al., 2005), and depended on erodible stream length, streambank height (assumed constant across the catchment at $3.5 \mathrm{~m}$ after Hancock et al., 2007), bankfull discharge, and reach slope. Erodible stream length for each subcatchment was derived from Hancock et al. (2007).

The model estimated deposition of suspended sediment on hillslopes, floodplains and in reservoirs. Hillslope deposition was a fraction of gross hillslope erosion defined by 1 minus the hillslope sediment delivery ratio (HSDR). Suspended sediment routing and floodplain deposition were defined as in previous versions of CatchMODS (Newham et al., 2004), and retained the algorithms of Prosser et al. (2001). Deposition in reservoirs was modelled assuming a trapping efficiency linked to reservoir storage capacity as in Hancock et al. (2007).

Several model parameters need calibration against measurements at monitoring stations (Vigiak et al., 2011a): (i) $f$ represents the fraction of water surplus generated on the hillslopes (as estimated with Howleaky2010) that contributes to stream flow, and is calibrated against mean annual flow ( $Q_{M A F}$; ML/y); (ii) the hillslope sediment delivery ratio HSDR, which is the fraction of gross erosion on the hillslopes that is delivered to the stream network; (iii) $\Delta$ is the fraction of gully and streambank wall particles $<63 \mu \mathrm{m}$, i.e. particles that contribute to suspended sediment load rather than bed load; and (iv) $\beta$ is the coefficient that regulates bank erosion rate. The parameters HSDR, $\Delta$ and $\beta$ are all calibrated against average annual sediment loads (t/y; Vigiak et al., 2011a). The two model configurations (i.e. informed by the two erodibility 
Vigiak et al., Impact of soil erodibility factor estimation on the distribution of sediment loads: the Latrobe River catchment case study

sets) were calibrated against the average annual suspended sediment load estimates at ten water quality monitoring stations of the catchment for the period 1990-2005 (Vigiak et al., 2011b). The ten monitoring station dataset was relatively rich for Australian conditions (e.g. Wilkinson et al., 2009), and encompassed a wide range of upstream areas (62 to $4252 \mathrm{~km}^{2}$ ) to which erosion processes contributed each different amounts of suspended sediment, thus providing a good basis for correct calibration of the sediment parameters. The model performance was assessed in terms of Nash-Sutcliffe Efficiency (Nash and Sutcliffe, 1970) of specific sediment yield predictions $\left(\mathrm{t} / \mathrm{km}^{2} / \mathrm{y}\right)$.

\section{MODEL RESULTS}

Calibration against mean annual flow at the ten monitoring stations yielded a water surplus fraction parameter $\mathrm{f}=0.8$, i.e. $80 \%$ of water surplus estimated with Howleaky 2010 contributed to streamflow, and $20 \%$ to recharge to deep aquifers. Water calibration was very good, with efficiency in the estimation of mean annual flow $\left(Q_{M A F} ; \mathrm{ML} / \mathrm{y}\right)$ of 0.92 and estimation of annual loads $(Q ; \mathrm{ML} / \mathrm{y})$ over the period of 0.87 . Notwithstanding the high model efficiency, streamflow in the upmost stations was under-estimated, i.e. it is likely that HowLeaky2010 water surplus estimation was too low under forest or plantations.

After calibration of the sediment parameters, both model configurations achieved high efficiencies in estimating average annual loads (Table 2). Efficiencies in estimating specific sediment load were, however, much lower. Specific sediment loads are less sensitive to the most downstream stations and therefore can be used to achieve the best balance of different sources of sediment across the catchment (Vigiak et al., 2011a).

Figure 3 shows the scatterplot of model predictions of specific sediment loads against observations. The two configurations showed similar scatter around the $1: 1$ line, and poorer fitting at stations with specific sediment loads $<5 \mathrm{t} / \mathrm{km}^{2} / \mathrm{y}$. The poorest performance of the local K dataset configuration was for the most downstream station " 226227 ", which had the highest specific sediment load (the right-most points in Figure 3), for which both models under-predicted sediment loads. However, even after removal of this datum, the model fit of the global $\mathrm{K}$ dataset was still better than the local K configuration; and therefore was overall the best model configuration.

\section{DISCUSSION AND CONCLUSIONS}

The two working hypotheses were only in part confirmed by the study results. The calibration of the hillslope delivery ratio (HSDR) did reduce the impact of absolute values of soil erodibility estimates on hillslope net erosion; indeed, as a result of the lower K values in the local dataset, the HSDR of the respective catchment model configuration was much higher than that in the global dataset case. However, the two model configurations resulted in different contribution of hillslope net erosion to suspended sediment loads. In both model configurations the contribution of landscape processes was the same, with estimates of contribution of suspended sediment loads to Lake Wellington of $1.5 \mathrm{kt} / \mathrm{y}$ sourced from gully erosion and $29 \mathrm{kt} / \mathrm{y}$ from streambank erosion. The hillslope net erosion contribution was estimated at $3.6 \mathrm{kt} / \mathrm{y}$ in the local $\mathrm{K}$ configuration, i.e. $11 \%$ of the estimated total of $34 \mathrm{kt} / \mathrm{y}$ to reach the lake. In contrast, for the global dataset configuration, hillslope net erosion was estimated at $9 \mathrm{kt} / \mathrm{y}, 23 \%$ of an estimated total sediment load to the lake of $40 \mathrm{kt} / \mathrm{y}$. Therefore, calibration of HSDR reduced but did not altogether erase the impact of soil erodibility $\mathrm{K}$ estimation on the contribution of suspended sediments in the catchment.

The spatial distribution of the soil erodibility factor $(\mathrm{K})$ resulted in a measurable impact on model performance, with the global $\mathrm{K}$ configuration better matching specific sediment load observations across the catchment than the local $\mathrm{K}$. The main difference in the attribution of $\mathrm{K}$ by the two approaches is due to the influence of climatic conditions on soil erodibility. Analysis of the global dataset indicated that, other conditions being equal, soil erodibility in warm climates is lower than in temperate climates (Salvador Sanchis et al., 2008). If we would assume warm climatic conditions rather than for the Cfb climate of the 
Vigiak et al., Impact of soil erodibility factor estimation on the distribution of sediment loads: the Latrobe River catchment case study

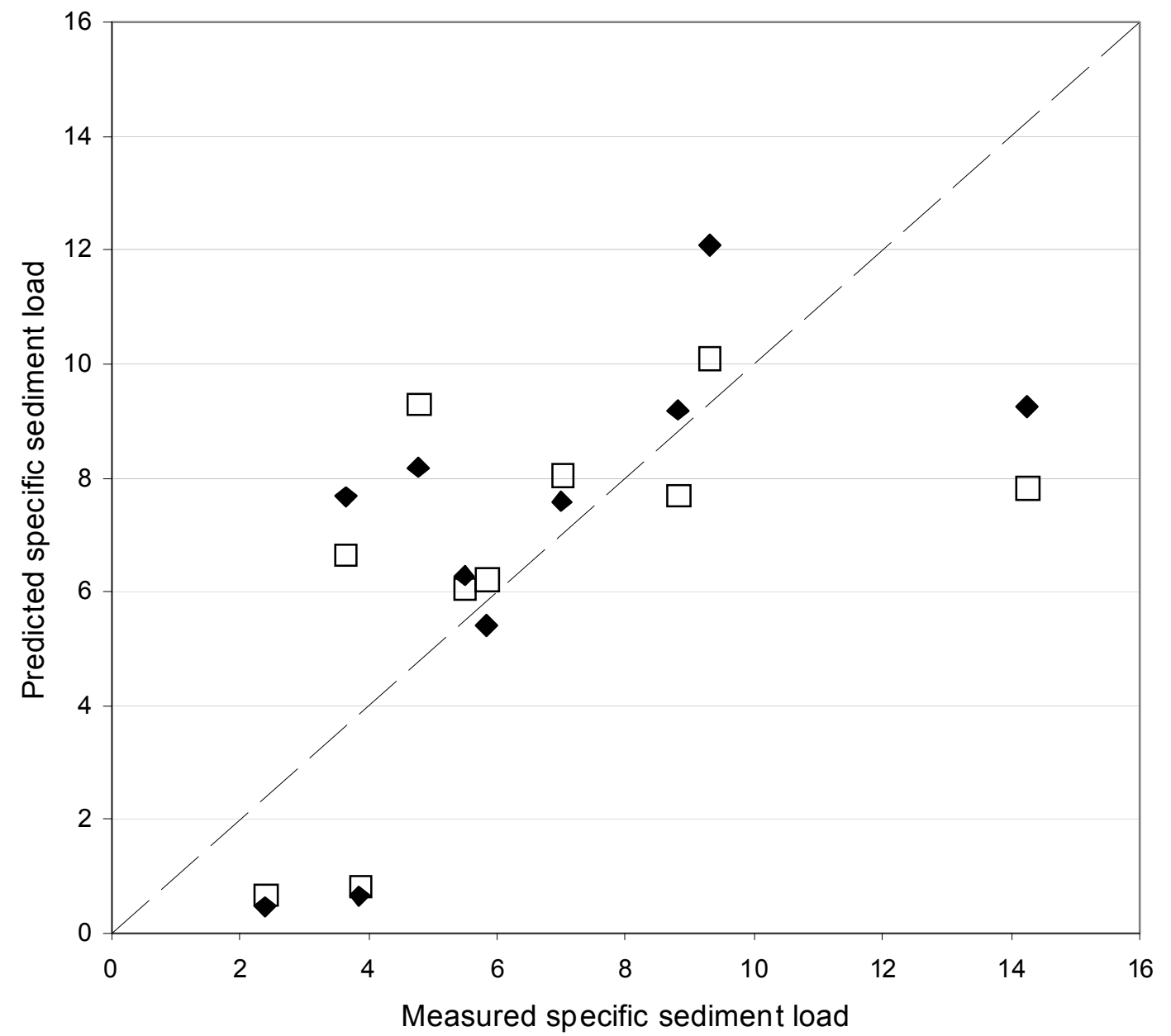

- Global K $\square$ Local K —-1:1 line

Figure 3. Scatterplot of specific sediment loads $\left(\mathrm{t} / \mathrm{km}^{2} / \mathrm{y}\right)$ predicted with the two model configurations against observations at ten gauging stations in the LaTrobe river catchment.

LaTrobe catchment, estimation of soil erodibility with the global dataset would yield erodibility values that were half to one third of those reported in Table 1, with some $\mathrm{K}$ values closely matching the 'local' dataset estimates. Temperate conditions cover only 14\% of Australia (Peel et al., 2007); it is possible that local experience on soil erodibility may be biased toward warm climatic conditions, which may lead to underestimates of soil erodibility in temperate areas in the south-eastern part of the continent.

Although the use of an approach that is sensitive to climatic conditions improved the catchment-scale model performance, specific sediment load efficiencies were low compared to values close to 0.5 reported for applications of similar models in other catchments of Victoria (Wilkinson et al., 2009; Vigiak et al., in press). Model errors in matching observations at low specific sediment yields warrant further research. Some source of error, such as errors introduced by artificial soil group boundaries, are inherent to the soil input data. These errors can only be reduced with extensive soil survey and mapping, particularly on public land. Better accounting for spatial variability of other processes, such as streambank erosion (e.g. Hancock et al., 2007) or in hillslope sediment delivery ratio (e.g. Vigiak et al., in press), may also lead to improved prediction of major sources of sediment loads in the LaTrobe river.

\section{ACKNOWLEDGMENTS}

We gratefully acknowledge the assistance of Andrew Hicks and Peter Manger (ANU) in developing the catchment scale model. Dr Scott Wilkinson (CSIRO) provided a very valuable dataset on streambank erosion without which this study could not have been conducted. 
Vigiak et al., Impact of soil erodibility factor estimation on the distribution of sediment loads: the Latrobe River catchment case study

\section{REFERENCES}

Aldrick, J.M, Hook, R.A, van de Graaff, R.H.M, Nicholson, B.M, O'Beirne, D.A, and Schoknecht, N.R. (1992). A Study of the Land in the Catchment of the Gippsland Lakes. Technical Communication 17. Department of Conservation and Natural Resources.

Borselli, L., Cassi, P., and Salvador Sanchis, P. (2009). Soil erodibility assessment for applications at watershed scale. In Constantini, E.A.C. (ed). Manual of methods for soil and land evaluation, Science Publisher, Chapter 5, pp 98-117.

De Rose, R., Wilson, D.J., Bartley, R., and Wilkinson, S. (2005) Riverbank erosion and its importance to uncertainties in large-scale sediment budgets. In Sediment budgets Proceedings of $7^{\text {th }}$ IAHS Scientific Assembly, Foz do Igunzu, Brazil, April 2005, 85-92.

EPA Victoria. (2002). Environmental conditions of rivers and streams in the Latrobe, Thomson, and Avon catchments. Environmental report 831.

Grayson, R.B., Tan, S.K., and Western, A. (2001). Estimation of sediment and nutrient loads into the Gippsland Lakes. CEAH report 2/01, University of Melbourne.

Hancock, G., Wilkinson, S., and Read, A. (2007). Sources of sediment and nutrients to the Gippsland Lakes assessed using catchment modelling and sediment tracers. CSIRO Land and Water Science report 70/07, $73 \mathrm{pp}$.

Isbell, R.F. (2002). The Australian Soils Classification Revised Edition. CSIRO Publishing, Melbourne.

Lu, H., Prosser, I.P., Moran, C.J., Gallant, J.C., Pristley, G., and Stevenson, J.G. (2003). Predicting sheetwash and rill erosion over the Australian continent. Australian Journal of Soil Research, 41, 10371062.

McClymont, D.J., Freebairn, D.M., Rattray, D.J., Robinson, J.B., and White, S. (2008). HowLeaky2008: exploring water balance and water quality implications of different landuses. Software V5.34.

Nash, J.E., and Sutcliffe, J.V. (1970). River flow forecasting through conceptual models part I - A discussion of principles. Journal of Hydrology, 10, 282-290.

Newham, L.T.H., Letcher, R.A., Jakeman, A.J., and Kobayashi, T. (2004). A framework for integrated hydrologic, sediment and nutrient export modelling for catchment-scale Management. Environmental Modelling and Software, 19, 1029-1038.

Northcote, K.H. (1979). A factual key for the recognition of Australian soils, Fourth Edition ed. Rellim Technical Publications, Coffs Harbour, NSW, Australia

Peel, M.C., Finlayson, B.L., and McMahon, T.A. (2007). Updated world map of the Köppen-Geiger climate classification. Hydrology and Earth System Sciences, 11, 1633-1644.

Rab, A., Smith, C., and Rees, D. (2002). The 1:250000 Statewide Soil Attribute Coverage Documentation. In. Department of Natural Resources and Environment, Government of Victoria, Centre for Land Protection Research, Epsom, Victoria.

Salvador Sanchis, M.P., Torri, D., Borselli, L., and Poesen, J. (2008). Climate effects on soil erodibility. Earth Surface Processes and Landforms, 33, 1082-1097.

Sargeant, I. J., and Imhof, M. P. (2011). Major Agricultural Soils of the West Gippsland Region. Department of Primary Industries, Victoria, Australia. http://www.dpi.vic.gov.au/dpi/vro/wgregn.nsf/pages/wg_soil_references [accessed 12 July 2011]

Vigiak, O., Newham, L.T.H., Whitford, J., Roberts, A.M., Rattray, D., Melland, A.R. (2011a). Integrating farming systems and landscape processes to assess management impacts on suspended sediment loads. Environmental Modelling and Software, 26, 144-162.

Vigiak, O. Sorn, N., McInnes, J., and Roberts, A.M. (2011b). Estimating constituent annual loads in the Gippsland Lakes Basin using Bootstrap and Bayesian methods. 25 ${ }^{\text {th }}$ IUGG General Assembly, Earth on the edge: science for a sustainable planet, $28^{\text {th }}$ June- $7^{\text {th }}$ July 2011, Melbourne, Australia, Conference CD.

Vigiak, O., Borselli, L., Newham, L.T.H., McInnes, J., and Roberts, A.M. (in press). Comparison of conceptual landscape metrics to define hillslope-scale sediment delivery ratio. Geomorphology, doi 10.1016/j.geomorph.2011.08.026

Wilkinson, S.N., Prosser, I.P., Rustomji, P., and Read, A.M. (2009). Modelling and testing spatially distributed sediment budgets to relate erosion processes to sediment yields. Environmental Modelling and Software, 24, 489-501.

Wishmeier, W.H., and Smith, D.D. (1978). Predicting rainfall erosion losses: a guide to conservation planning. U.S. Department of Agriculture, Agriculture Handbook 537. 